\title{
Implementasi Standar Akuntansi Keuangan (SAK) Dan Standar Akuntansi Pemerintah (SAP) Pada Laporan Keuangan Badan Layanan Umum Daerah (BLUD) Rumah Sakit Tani Dan Nelayan Pemerintah Daerah Kabupaten Boalemo
}

\author{
NIRMAWATI HUSAIN ${ }^{1}$, GRACE B. NANGOI², HENDRIK MANOSSOH³ \\ 1,2,3 Program Magister Akuntansi, Fakultas Ekonomi dan Bisnis Universitas Sam Ratulangi \\ Email: nirmawatihusain@gmail.com ${ }^{1}$, gracebn@yahoo.com² ${ }^{2}$, hendrikmanossoh@yahoo.com ${ }^{3}$
}

\begin{abstract}
Farmer and Fisherman Hospital utilizes accrual basis for its accounting and financial statements. It is also required to produce 2 types of financial statements based on: Financial Accounting Standard for non-profit organization and Government Accounting Standard for consolidation purposes. This research aims to analyze the implementation of Financial Accounting Standard and Government Accounting Standard on Financial Statements of Local Service Institution Farmer and Fisherman Hospital and their barriers. This is a qualitative exploratory study. Data were collected by interviews, participant observation and document analysis. Respondents consist of Finance and Accounting staff within the hospital. Findings indicate that the implementation of Financial Accounting Standard and Government Accounting Standard of Local Service Institution Farmer and Fisherman Hospital are supported by: (1) Regulation of Indonesian Ministry of Internal Affair number 61 year 2007, (2) Accounting policies, (3) Work program/plan, (4) Procedures supported by Standard Operating Procedures and (5) governance in describing the financial statements based on Financial Accounting Standard and Government Accounting Standard. On the other hand, barriers in implementing Financial Accounting Standard and Government Accounting Standard are firstly in its Human Resources: (1) Insufficient quantities and quality skilled human resources (2) Accounting Information System is not optimally utilized (3) Financial Statements are established manually, (4) Supporting documents are incomplete. Secondly, communication is not conducted well.
\end{abstract}

Keywords: Public Service Institution, Financial Accounting Standard, Government Accounting Standard, accrual, Financial Statements

\begin{abstract}
Abstrak. Penyelenggaraan akuntansi dan laporan keuangan Rumah Sakit Tani dan Nelayan Kabupaten Boalemo menggunakan basis akrual dan wajib menyusun laporan keuangannya dalam 2 versi, yakni berdasarkan pada Standar Akuntansi Keuangan karena bergerak di bidang organisasi nirlaba dan Standar Akuntansi Pemerintah karena tujuan untuk konsolidasi. Penelitian ini bertujuan untuk menganalisis implementasi Standar Akuntansi Keuangan dan Standar Akuntansi Pemerintah pada laporan keuangan BLUD di RSTN Kabupaten Boalemo serta kendala-kendala yang dihadapi. Metode yang digunakan adalah kualitatif eksploratif. Adapun teknik pengumpulan data yakni dengan wawancara, observasi berperanserta (participant observation), dan dokumentasi. Informan dalam penelitian ini adalah bagian keuangan RSTN Kabupaten Boalemo serta Bidang akuntansi BKAD Kabupaten Boalemo. Hasil penelitian menunjukkan bahwa implementasi SAK dan SAP pada laporan keuangan BLUD RSTN Kabupaten Boalemo didukung oleh peraturan yakni Permendagri 61 Tahun 2007, adanya kebijakan akuntansi, program/rencana kerja, prosedur yang didukung adanya SOP, dan tata kelola yang menguraikan penyajian laporan keuangan yang berdasarkan pada SAK dan SAP. Kendala-kendala yang dihadapi dalam penyusunan SAK dan SAP pada laporan keuangan BLUD RSTN Kabupaten Boalemo yakni yang kesatu adalah dari aspek Sumber Daya yang terdiri dari: (1) Sumber Daya Manusia yang belum memadai, (2) Pemanfaatan Sistem Informasi Akuntansi BLUD yang belum optimal, (3) penyusunan laporan keuangannya masih secara manual, (4) Kelengkapan dokumen pendukung yang belum memadai. Hal yang kedua adalah aspek komunikasi yang kurang baik.
\end{abstract}

Kata kunci: BLU/BLUD, SAK, SAP, akrual, laporan keuangan

\section{Pendahuluan}

Salah satu tuntutan masyarakat kepada pemerintah adalah peningkatan kinerja dalam pelayanan publik. Untuk memenuhi tuntutan tersebut salah satu reformasi yang telah dilakukan pemerintah dalam peningkatan pelayanan publik adalah dibidang keuangan yakni UU No. 17 Tahun 2003, UU No. 1 Tahun 2004, yang tujuannya adalah untuk menjadikan pola pengelolaan keuangan yang berfokus pada outcome, profesional, akuntabilitas, transparansi dan peningkatan kinerja. Pendekatan penganggaran berbasis kinerja yang berorientasi pada output ini semakin menjadi praktik yang dianut luas oleh pemerintah modern diberbagai negara. 
Dalam kaitannya, Undang-Undang Nomor 1 Tahun 2004 tentang Perbendaharaan Negara pada pasal 68 dan 69 menyatakan bahwa instansi pemerintah yang tugas pokok dan fungsinya memberi pelayanan kepada masyarakat dapat menerapkan pola pengelolaan keuangan yang fleksibel dengan menonjolkan produktivitas, efisiensi, dan efektivitas. Instansi demikian dengan sebutan sebagai Badan Layanan Umum (BLU), diharapkan pola seperti ini menjadi contoh konkrit yang menonjol dari penerapan manajemen keuangan berbasis pada hasil (kinerja). Hal ini sangat diperlukan bagi satuan kerja pemerintah daerah yang memberikan pelayanan kepada publik dengan cara mewiraswastakan pemerintah (enterprising the government).

Rumah Sakit Daerah merupakan satker pemerintah daerah yang memberikan pelayanan langsung kepada masyarakat. Biaya rumah sakit yang semakin meningkat dan rumah sakit dituntut untuk secara mandiri mengatasi masalah tersebut. Peningkatan biaya kesehatan ini merupakan fenomena tersendiri bagi rumah sakit pemerintah, karena segmen layanannya untuk kalangan menengah ke bawah. Sumber dana yang terikat pada berbagai aturan keuangan tidak memungkinkan bagi rumah sakit menyelesaikan permasalah keuangan yang sangat urgen seperti penyediaan obat-obat dan bahan habis pakai. Kondisi ini membuat rumah sakit pemerintah dituntut untuk melayani masyarakat khususnya kalangan menengah ke bawah dengan sumber dana yang terbatas serta berbagai macam aturan dan panjangnya birokrasi yang dihadapi (Agusalim dkk, 2013). Oleh karena itu, untuk mengatasi permasalahan tersebut, dibutuhkan manajerialisme dalam organisasi sektor publik karena adanya tuntutan masyarakat yang semakin besar agar sektor publik bisa menghasilkan produk barang/jasa yang memiliki kualitas yang lebih baik atau minimal sama dengan yang dihasilkan oleh sektor swasta. Oleh karena itu, untuk meningkatkan pelayanannya kepada masyarakat dan untuk memperoleh fleksibilitas manajemen, maka bentuk yang paling pas untuk sebuah rumah sakit adalah mengalihstatuskan menjadi BLUD.

Tujuan dari BLUD adalah untuk meningkatkan pelayanan kepada masyarakat dalam rangka memajukan kesejahteraan umum dan mencerdaskan kehidupan bangsa dengan memberikan fleksibilitas dalam pengelolaan keuangannya berdasarkan prinsip ekonomi dan produktivitas. Birokrasi pemerintah yang dikenal tidak efektif, tidak efisien dan lambat dalam memberikan pelayanan terhadap masyarakat akan diubah bentuknya menjadi BLU/BLUD agar lebih fleksibel dan responsiv dalam memberikan layanan secara optimal.

Secara umum kondisi BLU/BLUD masih belum memberikan pelayanan yang optimal. Terkait dengan kinerja keuangannya, dari hasil evaluasi yang dilakukan oleh BPKP pada Rumah Sakit Daerah (RSD) yang berstatus BLUD pada tahun 2014 terhadap 65 RSD menunjukkan bahwa 38 RSD termasuk kategori sehat dan 27 kategori sakit. Permasalahannya adalah penyusunan RBA yang belum sepenuhnya sesuai dengan aturan, penerapan sistem pengendalian intern belum memadai (sumber Warta Pengawasan BPKP, 2015). Dan pada tahun 2015 menunjukkan bahwa dari 102 RSD, 62 RSD mendapat predikat baik, dan 40 RSD berpredikat sedang. Kurang maksimalnya capaian untuk aspek kinerja keuangan antara lain disebabkan oleh rendahnya capaian rasio kas, periode penagihan piutang, imbalan aset tetap, perputaran persediaan dan rasio subsidi pasien (sumber Warta Pengawasan BPKP, 2016).

Dalam penyelenggaraan akuntansi dan laporan keuangan, BLU/BLUD wajib menyususn laporan keuangannya dalam dua versi. Berdsarkan PP No. 23 Tahun 2005 tentang Pengelolaan Keuangan Badan Layanan Umum pasal 26 (2) dinyatakan bahwa akuntansi dan pelaporan keuangan BLU diselenggarakan sesuai dengan Standar Akuntansi Keuangan (SAK) yang diterbitkan oleh asosiasi profesi akuntansi Indonesia. Di sisi lain sebagai Satker pada pemerintah, pada pasal 27 (7) menyatakan bahwa dalam melakukan penggabungan laporan keuangan BLU pada laporan keuangan pemerintah daerah dilakukan sesuai dengan Standar Akuntansi Pemerintah (SAP). Keunikan dari adanya kebutuhan penyusunan laporan keuangan dengan menerapkan kedua standar tersebut merupakan masalah tersendiri dalam pengelolaan keuangan BLU/BLUD.

Pemerintah Daerah Kabupaten Boalemo memiliki satu Rumah Sakit Umum milik pemerintah yakni Rumah Sakit Tani dan Nelayan (RSTN). Seperti pada umumnya untuk meningkatkan pelayanan kepada masyarakat pengelolaan keuangannya menerapkan pola pengelolaan keuangan BLUD.

Dilihat dari sisi SDM, Pelaksanaan akuntansi akan berjalan dengan baik apabila didukung oleh Sumber Daya Manusia (SDM) yang sesuai dengan beban kerja, bagi seorang dengan berlatar belakang 
pendidikan akuntansi, kemungkinan akan cukup mudah untuk memahami kedua model tersebut. Namun bagi BLUD yang pegawainya tidak berlatar belakang akuntansi serta pegawai yang pemahaman dasar akuntansinya masih kurang akan menjadi sulit bagi mereka. Dari kegiatan penelitian yang dilakukan, diketahui bahwa para pegawai yang ada di bagian keuangan RSTN Kabupaten Boalemo yang berlatar belakang pendidikan akuntansi hanya 3 orang serta pegawai lainnya belum sepenuhnya paham tentang dasar akuntansi.

Ariyati dkk (2016) dalam penelitiannya menyatakan bahwa Permasalahan di lapangan yang selama ini muncul dan menjadi temuan oleh pemeriksa ekternal diantaranya adalah kurangnya pemahaman mengenai perbedaan penerapan kedua standar tersebut, kurangnya kemampuan teknis pegawai terhadap akuntansi dan pelaporan keuangan BLUD, proses pelaksanaan yang belum sepenuhnya sesuai dengan aturan.

Lain halnya pada permasalahan penyusunan laporan keuangan dengan menggunakan sistem yang sudah ada. Dari hasil wawancara dengan bagian penyusun laporan keuangan RSTN Kabupaten Boalemo, laporan keuangan tidak disusun dengan bantuan aplikasi. Selama ini laporan keuangan disusun masih menggunakan secara manual (tanpa aplikasi) dengan bantuan komputer exel. Dikarenakan sistem tersebut masih dalam tahap penyempurnaan, fitur-fitur yang ada belum bisa mengcover kebutuhan transaksi RSTN itu sendiri. Selain itu masalah lainnya adalah tidak adanya SDM yang paham mengoperasikannya. Sehingga laporan keuangan masih disusun secara manual yang menyebabkan keterlambatan penyajian laporan keuangan.

Kemudian yang menjadi persoalan lain dalam penyusunan laporan keuangan yang ada di RSTN Boalemo adalah dari hasil informasi yang diperoleh bahwa dokumen-dokumen yang mendukung dalam penyusunan laporan keuangan bisa dikatakan kurang lengkap seperti dokumen/catatan persediaan obat yang sering tidak siap ketika dibutuhkan dan catatan dari asset yang nilainya selalu berubah-ubah. Kurang lengkapnya dokumen-dokumen tersebut menyebabkan terhambatnya penyusunan laporan keuangan. Serta berdasarkan hasil pemeriksaan oleh Kantor Akuntan Publik (KAP) pada tahun 2015 ditemukan bahwa belum dilakukannya perhitungan penyusutan asset untuk kelompok aktiva bangunan dan kelompok aktiva jalan, irigasi dan jaringan.

Tujuan yang ingin dicapai dalam penelitian ini adalah untuk menganalisis implementasi Standar Akuntansi Keuangan dan Standar Akuntansi Pemerintah pada laporan keuangan Badan Layanan Umum Daerah RSTN Kabupaten Boalemo serta kendala-kendala yang dihadapi.

\section{Metode penelitian}

Penelitian ini menggunakan metode kualitatif (qualitative method) dengan jenis pendekatan eksploratif. Menurut Gunawan (2016:80) penelitian dengan metode kualitatif menekankan analisis proses dari proses berfikir secara induktif yang berkaitan dengan dinamika hubungan antar fenomena yang diamati, dan senantiasa menggunakan logika ilmiah. Penelitian kualitatif bukan berarti tanpa menggunakan dukungan dari data kuantitatif, tetapi lebih ditekankan pada kedalaman berpikir formal dari peneliti dalam menjawab permasalahan yang dihadapi.

Metode penelitian kualitatif akan cocok digunakan untuk hal-hal yang salah satunya adalah bila masalah penelitian belum jelas, masih remang-remang atau mungkin malah masih gelap. Kondisi seperti ini cocok diteliti dengan metode kualitatif, karena peneliti kualitatif akan langsung masuk ke obyek, melakukan penjelajahan dengan grant tour question, sehingga masalah akan dapat ditemukan dengan jelas (Sugiyono, 2015:22).

Pendekatan eksploratori menurut Arikunto (2010:32) adalah pendekatan penelitian yang bertujuan untuk menggali suatu informasi. Menurut Jacob Vredenbregt (1985) dalam Silalahi (2012:27) mengemukakan bahwa penelitian eksplorasi, kadang-kadang disebut penelitian formulasi, biasanya dilakukan bilamana peneliti belum memiliki pengetahuan atau gambaran yang jelas tentang situasi masalah atau kurang memiliki atau tak ada sama sekali informasi mengenai masalah yang terjadi. Penelitian ini bertolak dari suatu permasalahan tertentu yang hanya samar-samar dipahami secara teoritis.

Dalam penelitian ini teknik pengumpulan data yang ditempuh adalah melalui observasi partisipatif berperanserta (participant observation), wawancara mendalam (in depth interview), dan secara dokumentasi (documentation). Dan untuk teknik pengujian keabsahan data dalam penelitian ini meliputi: 
uji kredibilitas yang dilakukan dengan perpanjangan pengamatan, peningkatan ketekunan dalam penelitian dan triangulas; uji Transferability (validitas eksternal); dan uji dependability (reliabilitas).

Bedasarkan latar belakang dan permasalahan yang telah di tetapkan pada bab sebelumnya, maka yang menjadi pertanyaan riset pada penelitian adalah :

1. Bagaimanakah implementasi SAK dan SAP pada laporan keuangan BLUD di RSTN Pemerintah Daerah Kabupaten Boalemo?

2. Kendala-kendala apa yang dihadapi dalam implementasi SAK dan SAP pada laporan keuangan BLUD di RSTN Pemerintah Daerah Kabupaten Boalemo?

Setelah pertanyaan riset, maka langkah berikutnya adalah membangun proposisi yakni :

1. Penerapan Standar Akuntansi Keuangan (SAK) dan Standar Akuntansi Pemerintah (SAP) pada laporan keuangan BLUD di RSTN Kabupaten Boalemo secara optimal harus didukung oleh peraturan yang telah ditetapkan, kebijakan, Program, prosedur dan tata kelola yang baik.

2. Kendala-kendala dalam penerapan Standar Akuntansi Keuangan (SAK) dan Standar Akuntansi Pemerintah (SAP) pada laporan keuangan BLUD di RSTN Kabupaten Boalemo terdiri dari: sumber daya, komunikasi, disposis/sikap dan struktur birokrasi.

\section{Model analisis}

Model analisis penelitian ini dapat digambarkan dalam kerangka konseptual penelitian seperti pada gambar 3.1 berikut ini:

\section{Gambar 3.1. Kerangka Konseptual Penelitian}

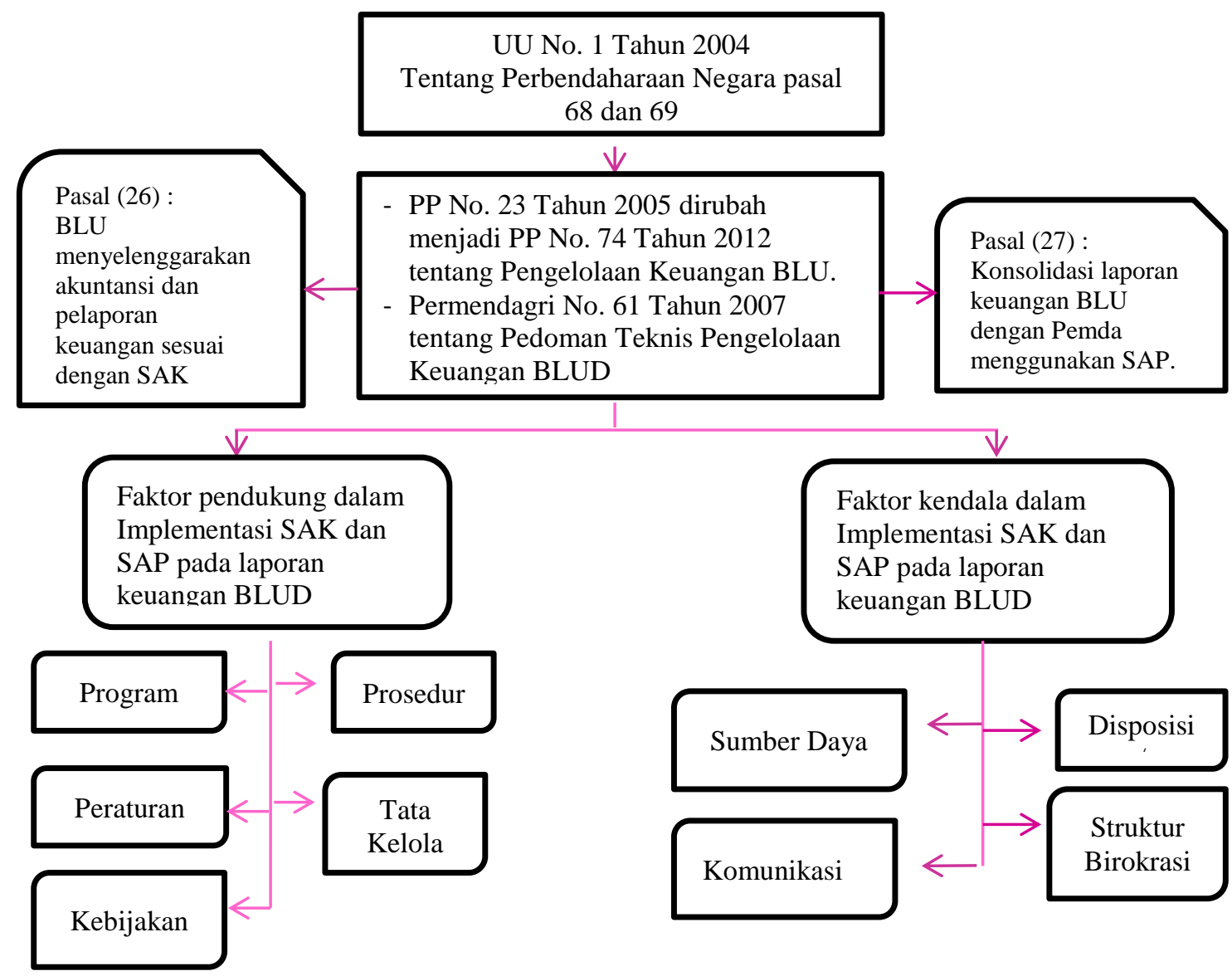

\section{Pembahasan}

Untuk menjawab masalah pertama yaitu "Bagaimana Implementasi SAK dan SAP Pada Laporan Keuangan BLUD RSTN Boalemo", di temukan beberapa tema yang sudah dikategorisasikan yakni peraturan (pelaksanaan yang sudah sesuai dengan Permendagri 61 Tahun 2007), adanya kebijakan 
akuntansi yang mendukung, Program, prosedur, tata kelola yang menjelaskan pelaksanaan laporan keuangan yang berdasarkan pada SAK dan SAP.

Dan untuk menjawab masalah yang kedua yakni "Kendala-kendala apa yang dihadapi dalam penyusunan SAK dan SAP pada laporan keuangan BLUD RSTN Boalemo", di temukan beberapa kendala di antaranya dari aspek Sumber daya yang terdiri dari Sumber Daya Manusia, Sistem Informasi Akuntansi yang belum optimal, penyusunan laporan keuangan masih manual dan dokumen sumber yang belum memadai. Dan aspek kedua adalah komunikasi informasi yang kurang baik.

\section{Pelaksanaan SAK dan SAP pada laporan keuangan BLUD RSTN Kabupaten Boalemo}

Implementasi SAK dan SAP Pada Laporan Keuangan BLUD RSTN Kabupaten Boalemo dapat dilihat dari pelaksanaan yang didukung oleh peraturan (pelaksanaan yang sudah sesuai dengan Permendagri 61 Tahun 2007 ), adanya kebijakan akuntansi yang mendukung, Program, prosedur, dan tata kelola yang menjelaskan pelaksanaan laporan keuangan yang berdasarkan pada SAK dan SAP.

\section{Peraturan}

Dari hasil wawancara diperoleh bahwa penyusunan laporan keuangan di RSTN sudah sesuai dengan peraturan yang berlaku yakni sesuai dengan Permendagri 61 Tahun 2007 tentang Pedoman Teknis Pengelolaan Keuangan Badan Layanan Umum Daerah. Koontz dkk (1986) dalam Edison (2016:40) mengemukakan bahwa intisari suatu peraturan ialah bahwa hal itu mencerminkan keputusan manajerial bahwa sesuatu tindakan harus dilakukan atau tidak boleh dilakukan. Peraturan merupakan salah satu aspek pendukung dalam pelaksanaan atau dalam menjalankan suatu kegiatan untuk mencapai tujuan organisasi termasuk dalam penyusunan laporan keuangan yang berdasarkan pada SAK dan SAP di RSTN Kabupaten Boalemo. Menurut Edison dkk (2016:41) dengan adanya peraturan karyawan dapat mengetahui tentang kewajiban yang harus dipenuhi, batasan yang harus dipatuhi dan hak-hak yang akan diterima.

Penelitian ini mengkonfirmasi hasil penelitian dari Surianto (2012) tentang Evaluasi Pelaksanaan Penerapan BLUD di RSUD Undata Provinsi Sulawesi Tengah dengan hasil penelitiannya adalah pelaksanaan penerapan PPK-BLUD RSUD Undata secara umum sesuai dengan Permendagri 61 Tahun 2007. Yang menunjukkan pola tata kelola, RAB dan laporan keuangan sesuai dengan standar.

Ketidakkonsistenan terhadap peraturan akibatnya seperti yang terlihat pada hasil penelitian yang dilakukan oleh Susandi dkk (2017), hasil penelitiannya menujukkan bahwa tidak adanya perbedaan kinerja keuangan dan efesiensi proses internal sebelum dan sesudah implementasi PPK-BLUD, hal ini disebabkan oleh manajemen RSUD Klungkung yang belum optimal menerapkan peraturan yang diterapkan yakni Permendagri Nomor 61 tahun 2007.

\section{Kebijakan}

Selain adanya peraturan yang mendukung penyusunan laporan keuangan BLUD, RSTN Kabupaten Boalemo dalam rangka meningkatkan akuntabilitas keuangannya membuat suatu pedoman akuntansi berupa kebijakan akuntansi yang digunakan sebagai acuan untuk membukukan transaksi keuangan dan untuk menyusun laporan keuangan. Dan berdasarkan observasi yang dilakukan, penyusunan kebijakan akuntansinya berdasarkan pada Standar Akuntansi Pemerintah.

Kebijakan merupakan keputusan dari pimpinan tentang arah pedoman atau yang belum diatur, bukan untuk kegiatan yang berulang-ulang. Jadi kebijakan ini tidak bisa digunakan sebagai prosedur atau peraturan karena sifatnya tidak berlaku untuk umum. Dengan adanya kebijakan ini, pelaksana tugas dapat bergerak gesit dan dilindungi oleh payung hukum (Edison dkk, 2016:39).

Karena suatu kebijakan sangat mendukung dalam hal pelaksanaan suatu tujuan dalam organisasi, maka dituntut komitmen untuk menerapkannya. Sama halnya seperti yang terlihat pada penelitian Satrio dkk (2016) dalam penelitiannya tentang implementasi Standar Akuntansi Pemerintah Berbasis Akrual di Kabupaten Jombang, dengan hasil penelitiannya menunjukkan bahwa pimpinan berserta jajaran SKPD memiliki komitmen dalam implementasi SAP berbasis akrual dimana perangkat regulasi dan kebijakan juga telah dibuat, disosialisasikan dan diimplementasikan. 


\section{Program}

Program merupakan salah satu pendukung dalam pencapaian tujuan pelaksanaan kegiatan. Dalam membuat perencanaan program kerja organisasi seluruh pelaku organisasi haruslah terlibat secara aktif. Setiap manajer dari masing-masing harus mengambil peran sesuai dengan fungsinya, yaitu untuk menjabarkan sasaran (objective) ke dalam program kerja atau rencana tindakan, yang didalamnya memuat: 1) Siapa yang melakukan atau siapa yang bertanggungjawab atas tugas tersebut; 2) menjelaskan ukuran atau target yang harus dicapai; 3) Menjelaskan mengenai batas waktu atau tanggal penyelesaian; dan 4) menetapkan alokasi biaya yang diperlukan dari masing-masing program (Edison dkk, 2016:38).

Dari informasi yang diperolah bahwa RSTN Kabupaten Boalemo sudah terdapat/memiliki program kerja yang disebut Rencana Operasional Kerja (ROK) untuk mencapai tujuan dari organisasi. Tetapi untuk program yang ada di bagian keuangan khususnya dalam rangka penyusunan laporan keuangan tidak ada, karena itu sudah menjadi tupoksi dari bagian keuangan itu sendiri dan tidak terdapat alokasi biaya dalam penyelesaian penyusunan laporan keuangan, namun untuk target waktu yang ditentukan dalam penyelesaian penyusunan laporan keuangan sudah ada dan juga terdapat pada Permendagri ataupun pada PSAP 13 mengenai batas waktu penyampaian laporan keuangan.

\section{Prosedur}

Berdasarkan hasil wawancara diperolah bahwa RSTN Kabupaten Boalemo telah memiliki SOP. Salah satu dari aspek struktur yang penting dari setiap organisasi adalah adanya prosedur operasi yang standar (Standard Operating Procedures atau SOP). SOP menjadi pedoman bagi setiap implementor dalam bertindak Edward (1980) dalam Mulyadi (2016:68). Edison dkk (2016:39) juga mengatakan bahwa keberadaan prosedur ini menjadi sangat penting, tujuannya agar tidak terjadi tumpang tindih dan memperjelas tugas dan tanggungjawab, sehingga keputusan-keputusan dapat diambil dengan cepat.

Dalam banyak kasus, perusahaan membuat perencanaan yang gemilang, tapi tidak memiliki prosedur, sehingga dalam implementasinya banyak yang mengalami hambatan serta ada celah penyimpangan. Seperti terlihat pada hasil penelitian dari Munir (2016) yakni belum adanya manual prosedur yang jelas khususnya tentang penyusunan anggaran, sehingga sulit menyelesaikan penyusunan anggaran sesuai tujuan dan harapan organisasi.

Edison dkk (2016:39) juga mengatakan bahwa keberadaan prosedur ini menjadi sangat penting, tujuannya agar tidak terjadi tumpang tindih dan memperjelas tugas dan tanggungjawab, sehingga keputusan-keputusan dapat diambil dengan cepat. Dalam banyak kasus, perusahaan membuat perencanaan yang gemilang, tapi tidak memiliki prosedur, walhasil dalam implementasinya banyak yang mengalami hambatans serta ada celah penyimpangan. Seperti terlihat pada hasil penelitian dari Munir (2016) yakni belum adanya manual prosedur yang jelas khususnya tentang penyusunan anggaran, sehingga sulit menyelesaikan penyusunan anggaran sesuai tujuan dan harapan organisasi.

\section{Tata kelola}

Tata kelola pada pelaksanaan penyusunan laporan keuangan di RSTN Kabupaten Boalemo dapat dilihat dari: 1) penyusunan laporan keuangan BLUD yang berdasarkan pada 2 standar yakni berdasarkan pada SAK dan SAP; 2) laporan keuangan RSTN Kabupaten Boalemo telah diaudit oleh auditor eksternal yakni dari Kantor Akuntan Publik (KAP) 2 tahun berturut-turut.

Tata kelola juga menyangkut pengelolaan suatu organisasi dengan meningkatkan prinsip akuntabilitas. Akuntabilitas menurut Mardiasmo (2002:20) adalah kewajiban pihak pemegang amanah (agent) untuk memberikan pertanggungjawaban, menyajikan, melaporkan, dan mengungkapkan segala aktivitas dan kegiatan yang menjadi tanggungjawabnya kepada pihak pemberi amanah (principal) yang memiliki hak dan kewenangan untuk meminta pertanggungjawaban tersebut.

Sementara untuk penyusunan laporan keuangan yang berdasarkan SAP sudah mengacu pada PSAP 13 tentang penyajian laporan keuangan BLUD berbasis akrual. Restianto dan Icuk (2015:105) menyatakan bahwa salah satu prinsip akuntansi yang dapat digunakan dalam penyelenggaraan akuntansi BLUD adalah basis akuntansi. Basis akuntansi yang digunakan dalam sistem akuntansi BLU/BLUD adalah basis akrual untuk pengakuan pendapatan, biaya dalam LO serta untuk pengakuan asset, kewajiban, dan ekuitas dana dalam Neraca. 
Penelitian ini berbeda dengan penelitian sebelumnya yang di lakukan oleh Ida Rosnida dkk (2016) pada RSUD Waled Cirebon tentang Identifikasi Eksisting Sistem Akuntansi BLUD Kabupaten Cirebon, yang dalam penelitianya mengemukakan bahwa selama ini dalam menyusun laporan keuangannya masih berpedoman pada Standar Akuntansi Keuangan (SAK) dan belum menggunakan Standar Akuntansi Pemerintah (SAP).

Tata kelola pelaksanaan penyusunan laporan keuangan yang baik dapat dinilai dengan melihat pada kualitas laporan keuangan yang diukur dari opini auditor. Pemeriksaan oleh auditor dilakukan agar tercipta akuntabilitas dan transparansi. Akuntabilitas tersebut dapat dilihat dari adanya antara lain opini yang diberikan auditor terhadap laporan keuangan yang diperiksa. Dengan diperolehnya opini WTP menunjukkan akuntabilitas semakin baik dan terlaksana tata kelola yang baik pula.

\section{Kendala-kendala dalam Pelaksanaan SAK dan SAP pada laporan keuangan BLUD RSTN Kabupaten Boalemo}

Kendala-kendala yang dihadapi dalam penyusunan SAK dan SAP pada laporan keuangan BLUD RSTN Kabupaten Boalemo meliputi dua aspek yakni dari aspek Sumber daya yang terdiri dari Sumber Daya Manusia yang belum memadai, Sistem Informasi Akuntansi yang belum optimal, penyusunan laporan keuangan masih manual dan dokumen sumber yang belum memadai. Aspek kedua adalah komunikasi informasi yang kurang baik.

\section{Sumber Daya Manusia}

Berdasarkan hasil penelitian yang telah dilakukan di RSTN Boalemo di temukan beberapa permasalahan pada penerapan penyusunan laporan keuangan BLUD antara lain adalah terbatasnya sumber daya manusia yang memiliki kapabilitas yang mumpuni. Di antaranya adalah sebagian pihak belum memahami prinsip PPK BLUD, penempatan tenaga ahli yang tidak sesuai dengan basik pendidikannya, jumlah dari personil/tenaga ahli akuntansi yang ada di RSTN masih kurang.

Robin Kessler (2008) dalam Edison dkk (2016:142) menulis pendapat Dennis Deans tentang hubungan Sumber Daya Manusia yakni 50/50 antara tujuan dan kompetensi. Dia mengatakan bahwa, untuk sukses harus ada keseimbangan sejati antara apa yang dicapai dan bagaimana hal itu dicapai. Makna 50/50 adalah keseimbangan dalam memandang pencapaian tujuan dengan kompetensi, sebab untuk mencapai tujuan, pegawai yang ada harus memiliki kemampuan dan memahami apa yang semestinya ia kerjakan. Nawawi (2006:309) menyatakan bahwa SDM sebagai pekerja yang dapat dihitung jumlahnya adalah asset suatu organisasi, sedang SDM sebagai potensi (fisik dan psikis) yang dimanifestasikan menjadi keterampilan atau keahlian kerja adalah modal atau investasi yang harus dihargai berbeda antara satu dengan yang lain.

Hasil penelitian ini mengkonfirmasi hasil dari penelitian Nadilla dkk (2016) mengenai Indentifikasi permasalahan penerapan PPK BLUD yang dilakukan pada Rumah Sakit Permata dan Rumah Sakit Berlian di Aceh yakni terbatasnya sumber daya manusia yang memiliki kapabilitas yang mumpuni dan kurangnya komitmen manajemen untuk menerapkan konsep BLUD sebagai entitas bisnis. Puspadewi dan Rosi (2013) dalam hasil penelitiannya menyatakan bahwa kendala yang sejauh ini masih ada didalam Rumah Sakit dan mempengaruhi kinerja adalah belum semua pegawai yang mengerti dan paham tentang pengelolaan keuangan BLUD.

\section{Aplikasi Sistem Informasi Akuntansi BLUD}

Berdasarkan hasil penelitian dan hasil wawancara, diperoleh bahwa RSTN itu sendiri telah mengaplikasikan Sistem Informasi Akuntansi (SIA BLUD) Akan tetapi kenyataan yang ditemui dilapangan bahwa sampai sekarang ini pemanfaatan sistem belum dimanfaatkan secara optimal oleh pihak pengelola keuangan RSTN. Hal ini disebakan oleh ASN yang ada di bagian keuangan belum paham dengan sistem tersebut, fitur-fitur dari aplikasi tersebut belum bisa mencover kebutuhan transaksi dari rumah sakit. Dengan belum optimalnya penerapan SIA BLUD tersebut akibatnya penyusunan laporan keuangan masih dilakukan secara manual, dan tidak memiliki BAS yang menjadi acuan dalam penyusunan laporan keuangannya dan dalam menyusun laporan keuangannya hanya berdasarkan pada kodefikasi akun secara umum. 
Sistem Informasi Akuntansi menurut Rama dan Jones (2008:6) adalah suatu subsistem dari SIM yang menyediakan informasi akuntansi dan keuangan, juga informasi lain yang diperoleh dari pengolahan rutin atas transaksi akuntansi. Beberapa manfaat pengaplikasian Sistem Informasi Akuntansi menurut Mulyani (2014:6) adalah berikut ini:

1. Menyediakan informasi yang akurat dan tepat waktu, sehingga dapat melakukan aktivitas utama pada value chain secara efektif dan efisien.

2. Meningkatkan kualitas dan mengurangi biaya produk dan jasa yang dihasilkan.

3. Meningkatkan efisiensi.

4. Meningkatkan kemampuan dalam pengambilan keputusan.

5. Meningkatkan sharing knowledge.

6. Menambah efisiensi kerja pada bagian keuangan

Temuan ini mengkonfirmasi hasil penelitian yang dilakukan oleh Ramadhan dan Rony (2013) mengenai Analisis kendala implementasi SIA pada Universitas Sebelas Maret yang menyatakan bahwa kendala kendala yang terjadi antara lain: 1). Respon dari aplikasi SIA tergantung jaringan; 2). Kesulitan dalam menghasilkan laporan berdasarkan SAK dan SAP dengan mengguankan SIA karena sistem belum terintegrasi dengan sistem yang lain; 3). Informasi yang dihasilkan terkadang masih harus dilakukan verifikasi terlebih dahulu; 4). SDM yang menangani aplikasi SIA khususnya operator belum optimal; 5). Data yang diinput belum lengkap dan benar karena ada perbedaan pencatatan dalam BKU untuk masingmasing fakultas.

\section{Penyusunan laporan keuangan yang masih manual}

Salah satu akibat yang muncul pada RSTN Boalemo dengan adanya penyusunan laporan keuangan yang masih dilakukan secara manual adalah tahapan penyampaian laporan keuangan ke BKAD sebagai laporan konsolidasi sering terlambat. Dan untuk laporan keuangan triwulan sering tidak dibuat. Olehnya, untuk memaksimalkan penyusunan laporan keuangan alangkah baiknya penyusunan laporan keuangan dikendalikan dalam bentuk sistem yang terkomputerisasi sehingga memudahkan dan lebih efisien dari segi waktu.

Kendala ketepatan waktu penyajian laporan terkait dengan lama waktu yang dibutuhkan oleh organisasi untuk menghasilkan laporan keuangan. Semakin cepat waktu penyajian laporan keuangan, maka akan semakin baik untuk pengambilan keputusan. Permasalahannya adalah semakin banyak kebutuhan informasi, maka semakin banyak pula waktu yang dibutuhkan untuk menghasilkan berbagai informasi tersebut. Laporan keuangan mungkin disajikan tidak tepat waktu sehingga tidak relevan untuk pengambilan keputusan meskipun disajikan lebih awal (Mardiasmo, 2002:146).

Menurut Halim (2007:45), dari jenis informasi dan banyaknya laporan keuangan yang harus disampaikan ke pemerintah daerah atau kepada pemakai laporan keuangan lainnya, memang penyampaian informasi ini bisa dilakukan secara manual dalam bentuk cetak maupun elektronik. Namun, diketik atau cetak secara manual sulit untuk direalisasikan secara ideal karena terbatasnya waktu dan kemampuan manusia, tetapi dengan media elektonik seperti komputer dan jaringannya serta aplikasinya akan mempermudah pelaksanaan informasi keuangan daerah tersebut.

\section{Kelengkapan Dokumen pendukung yang belum memadai}

Salah satu kendala yang dihadapi dalam penyusunan laporan keuangan di RSTN adalah belum tersedianya dokumen yang menyajikan data lengkap seperti data persediaan obat, data/catatan aset yang selalu berubah-rubah, dan dokumen RBA/DPA yang selalu mengalami perubahan. Dokumen sumber merupakan kelengkapan pendukung yang penting karena digunakan sebagai dasar pencatatan akuntansi setiap transaksi. Dokumen sumber yang lengkap dan memadai dibutuhkan untuk menghasilkan laporan keuangan yang akurat, handal dan memadai.

Bodnar dan Hopwood (2003:248) mengatakan bahwa dokumentasi dari sistem akuntansi sangat penting, prosedur akuntansi harus diutamakan dalam manual prosedur akuntansi sehingga kebijakan dan instruksi bisa secara tegas diketahui dan diterapkan secara seragam. Mahmudi (2011:45) juga mengatakan bahwa dokumen sumber yang digunakan untuk menyusun laporan keuangan juga harus tersedia. Temuan ini mengkonfirmasi hasil penelitian dari Ariyati dkk (2016) dalam hasil penelitiannya menyatakan bahwa kendala yang dihadapi berupa sumber daya dan kelengkapan pendukungnya yang belum memadai. 
Untuk mendukung adanya ketersediaan dokumen/formulir/data tentang persediaan (misalnya persediaan obat yang menjadi masalah di RSTN) dalam suatu instansi alangkah baiknya di dukung dengan suatu aplikasi yang mengatur secara administrasi tentang persediaan obat tersebut. Karena dengan adanya sistem persediaan yang terkomputerisasi itu dapat membantu inventarisasi tentang persediaan obat. Seperti yang di paparkan oleh Achmad (2016) dalam penelitiannya tentang Analisis Peranan Sistem Inforamsi Akuntansi Persediaan Alat-Alat Kesehatan Dalam Rangka Memenuhi Kebutuhan Pelayanan Rawat Inap pada Rumah Sakit Umum Bahteramas Sulawesi Tenggara, yang dalam penelitiannya menunjukkan bahwa sistem informasi akuntansi persediaan yang diterapkan pada Rumah Sakit Umum Bahteramas Provinsi Sulawesi Tenggara cukup memadai khususnya persediaan alat kesehatan penunjang dalam memenuhi kebutuhan pelayanan rawat inap dan untuk memudahkan pembuatan laporan secara regular tentang persiapan data, memudahkan inventarisasi bukti investigasi, serta mampu mempresentasikan data sebagai bahan dalam pembuatan perencanaan dan penganggaran.

\section{Komunikasi informasi}

RSTN Kabupaten Boalemo tidak di dukung oleh proses komunikasi yang baik. Hal ini terlihat dari penyampain laporan keuangannya yang sering tidak tepat waktu dan pemakai laporan keuangan dalam hal ini BKAD Boalemo mengeluhkan tentang keterlambatan panyampaian laporan keuangan. Menurut Edward (1980) dalam Mulyadi (2016:68) salah satu yang mempengaruhi implementasi kebijakan adalah komunikasi. Untuk mencapai tujuan organisasi yang efektif dan efisien proses komunikasi yang baik sangat diperlukan.

Komunikasi suatu program hanya dapat dilaksanakan dengan baik apabila jelas bagi para pelaksana. Hal ini menyangkut proses penyampaian informasi, kejelasan informasi, dan konsistensi informasi yang disampaikan. Christhoper Hood dalam Parsons (2006:467) menyatakan Bahwa harus ada komunikasi yang sempurna di dalam dan diantara organisasi. Laporan keuangan yang dibuat merupakan informasi akuntansi dari aktivitas bisnis yang dilakukan yang selanjutnya mengkomunikasikannya kepada pemakai laporan keuangan atau pengambil keputusan.

Terlaksananya suatu tujuan organisasi dengan baik jika tercipta hubungan komunikasi yang baik pula. Sebagaimana yang digambarkan oleh Ariyanto (2015) dalam penelitiannya salah satu tentang pengaruh komunikasi terhadap kesiapan dalam penerapan standar akuntansi pemerintahan berbasis akrual. Hasil penelitiannya menunjukkan bahwa kualitas dari komunikasi berpengaruh positif terhadap kesiapan penerapan standar akuntansi pemerintahan yang berbasis akrual.

Proses komuniaksi akan berjalan dengan sempurna/baik jika memiliki tujuan untuk mencapai efektif dan efisien. Efektif yang dimaksudkan adalah dengan sumber daya yang ada diharapkan komunikasi dapat mencapai hasil yang maksimal. Dan efisien dimaksudkan disini adalah jika informasi yang disampaikan sebisa mungkin mendapatkan respon yang baik atau positif dari pemakai/pengguna informasi tersebut.

\section{Kesimpulan}

Kesimpulan dari penelitian ini adalah RSTN Kabupaten Boalemo dalam menerapkan penyusunan laporan keuangan yang berdasarkan pada 2 standar yakni berdasarkan SAK dan SAP di dukung oleh Peraturan, kebijakan, program, prosedur, dan tata kelola yang baik. Serta kendala-kendala yang dihadapi dalam pelaksanaan penyusunan laporan keuangan yang berdasarkan pada SAK dad SAP yaitu meliputi aspek Sumber Daya yang terdiri dari: 1) SDM yang belum memadai, 2) Pemanfaatan SIA BLUD yang belum optimal, 3) Penyusunan laporan keuangan yang masih manual, dan 4) Kelengkapan dokumen pendukung yang belum memadai. dan aspek komunikasi informasi yang kurang baik.

Penelitian ini telah diusahakan dan dilaksanakan sesuai dengan proses, namun demikian masih memiliki keterbatasan diantaranya adalah waktu penelitian yang sangat singkat dan waktu dari informan yang diwawancarai untuk dimintai keterangan lebih lanjut sangat terbatas. Dikarenakan informan tersebut memiliki kesibukan tersendiri.

Saran yang dapat diberikan dari penelitian ini adalah:

a. Membuat Pelatihan/Diklat/Kursus untuk meningkatkan kompetensi SDM dalam penyusunan laporan keuangan BLUD. 
b. Menempatkan seseorang yang sesuai dengan latar belakang pendidikannya dan kompetensinya.

c. Menyusun Bagan Akun Standar (BAS) untuk memudahkan kodefikasi akun dan memperhatikan BAS yang digunakan Pemda untuk memudahkan proses konsolidasian laporan keuangan.

d. Mengoptimalkan penggunaan Sistem Informasi Akuntansi (SIA-BLUD).

e. Perlu adanya komunikasi yang aktif oleh RSTN kepada BKAD dalam hal penyampaian informasi laporan keuangan sehingga laporan keuangan tersebut dapat digunakan secara maksimal oleh BKAD selaku pemakai laporan keuangan.

\section{Daftar pustaka}

Achmad, Nur Azizah. 2016. Analisis Peranan Sistem Informasi Akuntansi Persediaan Alat-Alat Kesehatan Dalam Rangka Memenuhi Kebutuhan Pelayanan Rawat Inap pada Rumah Sakit Umum Bahteramas Provinsi Sulawesi Tenggara.Vol. 1. No. 3 Tahun 2016. Hal. 61-73

Agusalim, Indar dan Alimin. 2013. Analisis Mekanisme Penganggaran Sebagai Alat Pengendalian Keuangan (Studi kasus pada Rumah Sakit Umum Anutapura Palu). Jurnal Administrasi dan kebijakan kesehatan. Vol.2 Nomor 1 Tahun 2013. Hal. 8-17

Arikunto, Suharsimi. 2010. Prosedur Penelitian: Suatu Pendekatan Praktik. Jakarta. Rineka Cipta.

Ariyanto, Dodik. 2015. Faktor-Faktor Yang Mempengaruhi Penerapan Standar Akuntansi Pemerintahan Berbasis Akrual. E. jurnal Akuntansi 13. ISSN 2302-8556. Hal 14-32.

Ariyati, Rina. Margani Pinasti dan Negina Kencono Putri. 2016. Penerapan Standar Akuntansi Keuangan (SAK) dan Standar Akuntansi Pemerintah (SAP) pada Sistem Akuntansi Badan Layanan Umum Universitas. Simposium Nasional Akuntansi XIX. Lampung. Hal 1-28

Bodnar, George H \& Williams S Hopwood. 2003. Sistem Informasi Akuntansi.

Alih Bahasa: Deddy Jacobus. Jakarta. Penerbit PT. Indeks, Kelompok Gramedia. indeks@cbn.net.id.

Edison, Emron. Yohny Anwar \& Imas Komariyah. 2016. Manajemen Sumber Daya Manusia (Strategi dan perubahan dalam rangka meningkatkan kinerja pegawai dan organisasi). Bandung. Alfabeta.

Gunawan, Iman. 2016. Metode Penelitian Kualitatif Teori dan Praktik. Jakarta. PT. Bumi Aksara.

Halim, Abdul. 2007. Akuntansi dan Pengendalian Pengelolaan Keuangan Daeran. Seri bunga rampai Manajemen Keuangan Daerah edisi revisi. Yogyakarta. UPP STIM YKPN YOGYAKARTA.

Mahmudi. 2011. Akuntansi Sektor Publik. Yogyakarta. UII Press.

Mardiasmo. 2002. Akuntansi Sektor Publik. Penerbit Andi OFFSET. Yogyakarta

Mulyadi, Deddy. 2016. Studi Kebijakan Publik dan Pelayanan Publik. Bandung. Alfabeta.

Munir, Saiful. 2016. Implementasi Penyusunan Anggaran Badan Layanan Umum dari Perspektif Good Governance ( Studi di Fakultas ekonomi dan Bisnis Universitas Brawijaya). Jurnal Ilmiah Administrasi Publik. JIAP vol. 2/Nomor 3/Tahun 2016. ISSN: 2302-2698. e-ISSN:2503-2887. Hal. 19-27

Nadilla, Trie. Hasan Basri dan Heru Fahlevi. 2016. Identifikasi Permasalahan Penerapan Pola Pengelolaan Keuangan Badan Layanan Umum Daerah (PPK-BLUD) Studi kasus pada Rumah Sakit permata dan Rumah Sakit Berlian. Jurnal Magister Akuntansi. Jurnal Magister Akuntansi. ISSN: 2302-0164. Hal 89-99.

Nawawi, H. Hadari. 2006. Kepemimpinan Mengefektifkan Organisasi. Jakarta. Gadjah Mada University Press.

Parsons, Wayne. 2006. Public Policy: Pengantar Teori dan Praktik Analisis Kebijakan. Jakarta. Kencana Prenada Media Group

Puspadewi, Febriana dan Rosi. 2013. Analisis Implementasi Pengelolaan Keuangan BLUD dan Dampaknya Terhadap Kinerja Pada Rumah Sakit Umum Daerah Nganjuk. Vol.2. No.2. 2013. Hal 10-34

Rama, Dasaratha V \& Frederick L. Zones. 2008. Sistem Informasi Akuntansi Edisi 18. Jakarta. Salemba Empat. 
Ramadhan, Adi Firma dan Rony K Moentoro. 2013. Analisis Kendala Implementasi Sistem Informasi Akuntansi Pada Perguruan tinggi Negeri. Seminar Nasional Sistem Informasi Indonesia (SESINDO). ISBN:978-979-18985-6-0. Hal 44-51

Restianto, Yanuar \& Icuk Rangga Bawono. 2015. Pengelolaan Keuangan BLU/BLUD. Yogyakarta. UPP STIM YKPN.

Republik Indonesia. Peraturan Pemerintah Nomor 23 Tahun 2005 Tentang Pengelolaan Keuangan Badan Layanan Umum. Jakarta. . Peraturan Menteri Dalam Negeri Nomor 61 Tahun 2007 Tentang Pedoman Teknis Pengelolaan Keuangan Badan Layanan Umum Daerah. Jakarta. . Peraturan Menteri Keuangan Nomor 217 / PMK.05 Tahun 2015 Tentang Pernyataan Standar Akuntansi Pemerintah Berbasis Akrual Nomor 13 Tentang Penyajian Laporan Keuangan Badan Layanan Umum.

Pemerintah. Peraturan Pemerintah Nomor 71 Tahun 2010 Tentang Standar Akuntansi

Rosnidah, Ida. Juwenah dan Apri Dwi Astuti. 2016. Identifikasi Eksisting Sistem akuntansi Badan Layanan Umum Daerah Pada Rumah Sakit Umum Daerah Kabupaten Cirebon. Jurnal Riset Akuntansi \& Keuangan. Vol. 4, No 2. Hal 32-46

Satrio, Dimas. Indrawati Yuhertiana dan Ardi Hamzah. 2016. Implementasi Standar Akuntansi Pemerintah Berbasis Akrual di Kabupaten Jombang. Volume 18, No 12016. ISSN 2338-8137. Hal 59-70.

Silalahi, Ulber. 2012. Metode Penelitian Sosial. Bandung. Refika Aditama.

Sugiyono, 2015. Memahami Penelitian Kualitatif. Bandung. Alfabeta.

Surianto. 2012. Evaluasi Pelaksanaan Penerapan Badan Layanan Umum Daerah (BLUD) Di RSUD Undata Provinsi Sulawesi Tengah. Volume 2.

Susandi, Nyoman Trio. I Ketut Budiartha dan Herkulanus B. Suprasto. 2017. Kinerja Keuangan dan Efesiensi Proses Internal Sebelum dan Sesudah Penerapan PPK-BLUD pada RSUD Kabupaten Klungkung. Volume 06 Nomor 04 Tahun 2017. No. 01 (2013) hal 35-41.

Warta Pengawasan BPKP. 2015. Mendorong Peningkatan Kinerja BUMD/BLUD. Vol.XXII/Nomor 9/Tahun 2015. ISSN:0854-0519

Warta Pengawasan BPKP. 2016. Kontribusi BPKP Dalam Pengawasan Pembangunan Kesehatan. Nomor 4/Tahun 2016. ISSN: 0854-0519 